http://ejournal.undip.ac.id/index.php/kapal

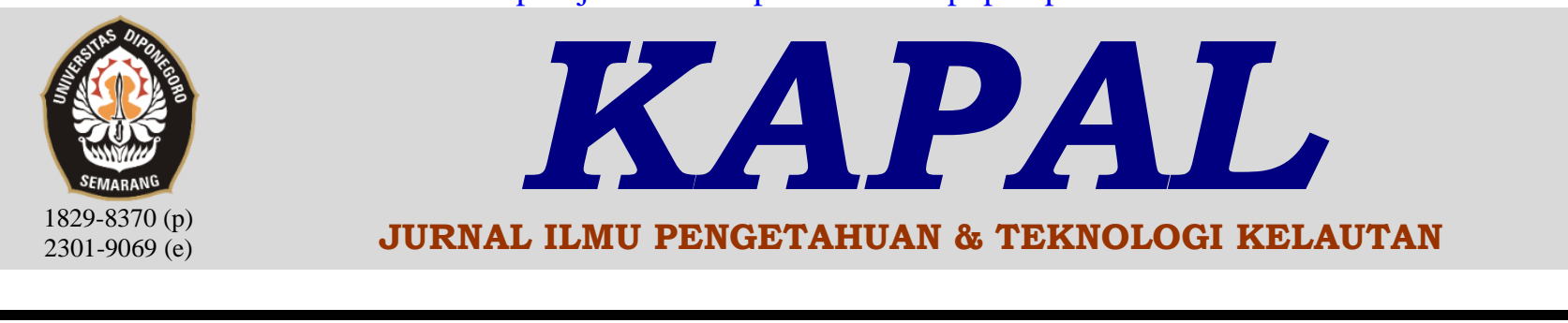

\title{
Analisis Kekuatan Konstruksi Graving Dock Gate Menggunakan Metode Elemen Hingga
}

\author{
Kharis Abdullah ${ }^{\left.l)^{*}\right)}$, Budie Santosa ${ }^{2)}$ \\ ${ }^{1)}$ Jurusan Teknik Bangunan Kapal, Politeknik Perkapalan Negeri Surabaya \\ Jl. Teknik Kimia, Kampus ITS, Surabaya, Indonesia 60111 \\ ${ }^{2)}$ Departemen Teknik Perkapalan, Institut Teknologi Sepuluh Nopember \\ Jl. Raya ITS, Sukolilo, Surabaya, Indonesia 60111
}

diajukan pada : 31/05/18 direvisi pada $: 20 / 06 / 19 \quad$ diterima pada $: 16 / 07 / 19$

\begin{abstract}
Abstrak
Graving dock gate merupakan salah satu bagian konstruksi daripada graving dock yang berupa konstruksi baja. Konstruksi graving dock gate yang berhadapan langsung dengan laut harus mampu menahan beban dari air laut setiap saat. Dengan melakukan variasi pada konstruksi pintu didapatkan hasil desain yang cukup optimal dari sisi kekuatan maupun sisi building cost. Pada penelitian ini dilakukan perhitungan kekuatan graving dock gate dengan menggunakan metode elemen hingga. Variasai dilakukan dengan empat jarak pembujur yaitu jarak pembujur $0.55 \mathrm{~m}, 0.60 \mathrm{~m}, 0.65 \mathrm{~m}$ dan $0.70 \mathrm{~m}$. Dengan bantuan software metode elemen hingga didapatkan hasil nilai tegangan maksimum von Mises masih dibawah $\mathrm{ReH} 235 \mathrm{~N} / \mathrm{mm}^{2}$ dan pintu dengan jarak pembujur $0.7 \mathrm{~m}$ memiliki tegangan maksimum von Mises terendah yaitu $108.58 \mathrm{~N} / \mathrm{mm}^{2}$ serta pintu dengan jarak pembujur $0.55 \mathrm{~m}$ memiliki tegangan maksimum paling tinggi yaitu $155.84 \mathrm{~N} / \mathrm{mm}^{2}$. Perhitungan building cost yang dilakukan, didapatkan pintu dengan jarak gading $0.65 \mathrm{~m}$ memiliki building cost yang paling rendah dan jarak gading $0.60 \mathrm{~m}$ memiliki building cost yang paling tinggi.
\end{abstract}

Copyright (C) 2019, KAPAL, 1829-8370 (p), 2301-9069(e)

Kata Kunci : Dock, Graving Dock Gate, Metode Elemen Hingga, Tegangan

\section{PENDAHULAN}

Graving dock merupakan salah satu fasilitas pendukung di galangan kapal. Graving dock merupakan sebuah kolam besar yang berada di tepi laut, secara umum konstruksi graving dock terdiri dari dinding samping, lantai, dinding depan, serta sebuah pintu (gate) yang berhubungan secara langsung dengan air laut [1]. Pada Gambar 1 terlihat longitudinal section graving dock dengan susunan keel block yang digunakan untuk dudukan kapal yang akan direparasi.

Pada Gambar 2 terlihat sebuah kapal yang berada pada graving dock yang sedang melakukan reparasi. Graving dock dapat digunakan untuk

*) Penulis Korespondensi :

Email : kharis.abdullah@ppns.ac.id proses docking hampir semua jenis kapal.

Semua graving dock harus memiliki sebuah pintu atau gate yang digunakan untuk keluar masuk kapal yang akan melakukan proses docking atau undocking [1]. Gate pada graving dock salah satu konstruksi yang penting untuk menahan air masuk ke dalam dock. Secara umum ada beberapa jenis graving dock gate yaitu flap gates, floating caisson gates, intermediate gates, sliding and rolling caisson gates, mitre gates dan lain-lain [2]. Pada Gambar 3 terlihat sebuah pintu dengan jenis floating caisson gates.

Proses operasional graving dock pada saat kapal akan masuk ke graving dock, dimana pintu akan dibuka dan ditutup kembali setelah kapal masuk ke dalam kolam. Setelah pintu ditutup maka air di dalam kolam akan dipompa keluar sehingga kolam mengering. Tekanan air laut akan 
menekan pintu sehingga pintu terkunci. Pekerjaan di kapal dilakukan setelah kolam mengering.

Setelah menyelesaikan pekerjaan, kolam akan diisi dengan air yang menyebabkan tekanan air dari kolam dan pantai menjadi seimbang. Tekanan air yang seimbang antara kolam dan pantai akan melepaskan kunci sehingga pintu dapat bergerak bebas. Graving dock gate atau pintu dock kolam memiliki karakteristik yang sama dengan kapal, pintu dapat mengapung di atas air sehingga mudah untuk dipindahkan [3].

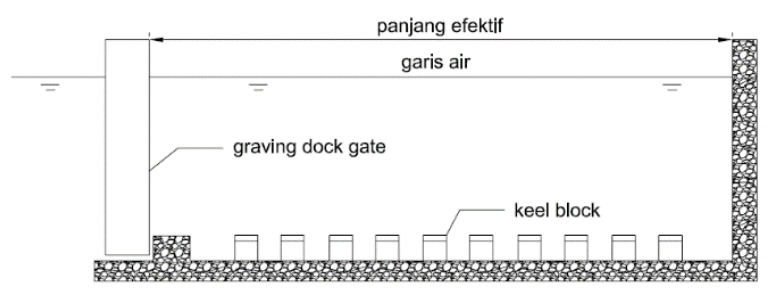

Gambar 1. Longitudinal section graving dock

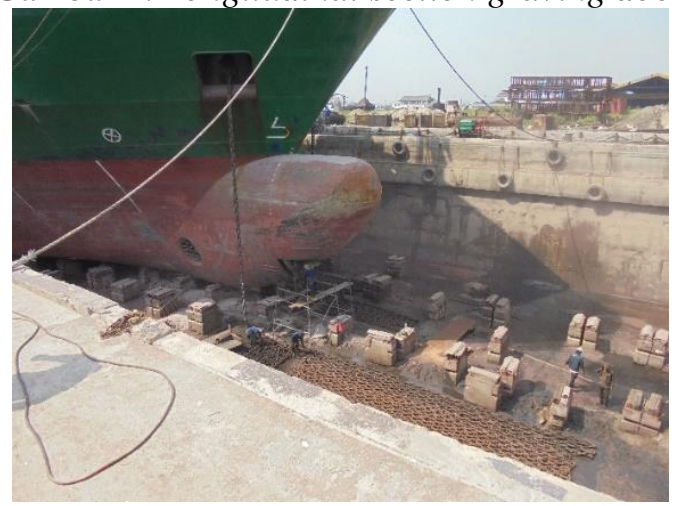

Gambar 2. Kapal berada pada graving dock

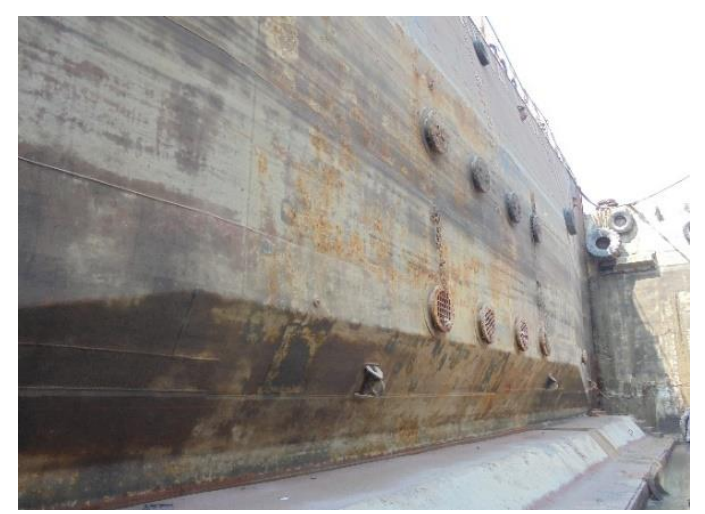

Gambar 3. Graving dock gate dengan jenis floating caisson gates

Graving dock gate memiliki struktur yang hampir sama dengan kapal, terdiri dari kulit pelat baja, penegar, sistem perpipaan dan lain-lain [4]. Pada saat beroperasi struktur pintu akan mendapatkan beban gaya gravitasi, tekanan hidrostatik air, angin dan arus [5]. Dalam menghitung kekuatan suatu struktur terdapat beberapa metode yaitu dengan rumus empiris, metode analisis yang disederhanakan, metode numerik seperti elemen hingga dan eksperimen.
Pada saat ini metode elemen hingga merupakan metode yang lebih disukai untuk memprediksi kegagalan struktur, deformasi struktur, pembebanan dalam berbagai bidang teknik [6].

Studi tentang struktur dan konstruksi bangunan laut berfokus pada pekerjaan numerik karena kompleksitas daripada bangunan laut tersebut. Penting untuk diketahui bahwa walaupun studi eksperimental memberikan wawasan fisik yang diperlukan, tugas prediktif seperti desain, analisis, dan evaluasi struktur kapal sering dilakukan dengan metode komputasi [7].

Pada saat ini, perhitungan metode elemen hingga dapat dilakukan dengan simulasi numerik dengan komputer melalui bantuan software. Contoh software untuk perhitungan dengan menggunakan metode elemen hingga yaitu SAP 2000, NASTRAN, ANSYS, LS-DYNA, dan lainlain. Dengan menggunakan software perhitungan kekuatan cukup efisien dan cepat [8]. Pemodelan dalam software ini terdapat beberapa tahapan. Tahapan-tahapan tersebut harus dilakukan secara benar agar model dapat di-running (proses perhitungan yang dilakukan oleh komputer) [9], beberapa tahapan dalam menggunakan software yaitu :

1. Preprocessing

Pada tahap preprocessing dilakukan pendefinisian masalah dengan melakukan penjabaran tipe-tipe elemen, geometri dan ukuran mesh.

\section{Solution}

Tahap ini dilakukan aplikasi beban, kondisi batas, dan penyelesaian.

\section{Postprocessing}

Pada tahap terakhir yaitu pembacaan hasil, seperti nodal displasmen, kontur diagram dan lain-lain.

Pada penelitian ini akan dilakukan analisa kekuatan graving dock gate dengan menggunakan metode elemen hingga dibantu dengan software sehingga proses perhitungan dapat dengan cepat dilakukan. Analisa kekuatan diperlukan karena graving dock gate setiap saat menerima beban dari air laut. Paket program ANSYS Mechanical APDL dipilih pada penelitian ini sebagai alat analisis metode elemen hingga. ANSYS Mechanical APDL merupakan salah satu paket software yang memiliki solver yang kuat [10].

Perhitungan kekuatan tidak lepas dari perhitungan building cost atau biaya pembangunan suatu konstruksi, dengan mengetahui kekuatan suatu konstruksi maka kegagalan dalam proses pembangunan dapat diminimalisir. Pada penelitian ini juga akan dilakukan perhitungan building cost pada setiap variasi desain pintu dock sehingga dapat 
dihasilkan pintu dock yang optimum dari sisi kekuatan dan ekonomisnya. Lebih lanjut, hasil dari penelitian ini dapat menjadi salah satu bahan kajian analisis kekuatan konstruksi gate dock dengan model dan desain yang lain.

\section{METODE}

\subsection{Desain dan Konstruksi}

Di dalam penelitian ini, graving dock gate yang digunakan mengacu pada ukuran daripada graving dock yang akan digunakan yaitu berdimensi panjang $150 \mathrm{~m}$, lebar $27 \mathrm{~m}$ dan tinggi $8 \mathrm{~m}$. Pada Gambar 4 dapat dilihat ilustrasi ukuran graving dock.

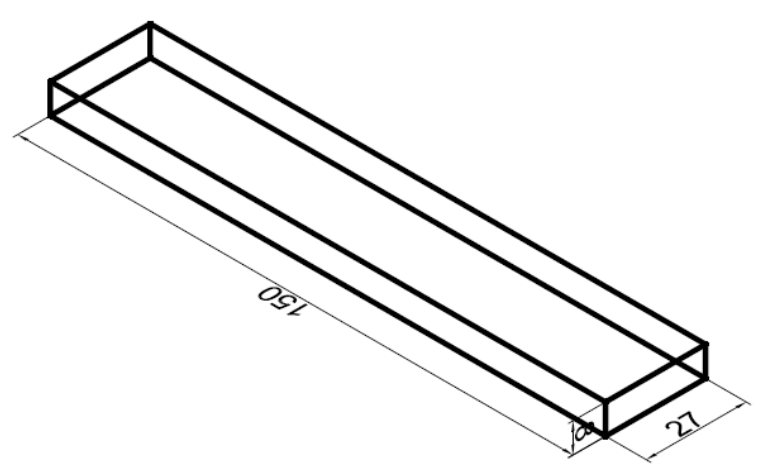

Gambar 4. Ilustrasi ukuran graving dock

Desain graving dock gate dengan jenis floating caisson gates, dimana model pintu dock ini dapat mengapung dan dapat tenggelam ketika diberikan air balas. Pada Gambar 5 dapat dilihat desain graving dock gate tampak depan, terdapat beberapa lubang air dan fender. Ukuran utama pintu dock yaitu panjang $28.2 \mathrm{~m}$, lebar $1.6 \mathrm{~m}$, dan tinggi $7.0 \mathrm{~m}$

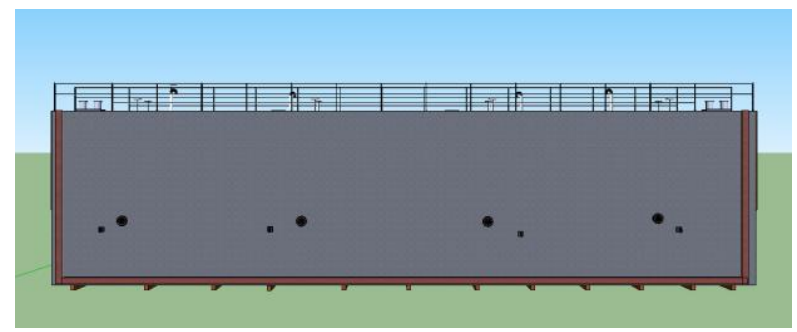

Gambar 5. Desain graving dock gate

Pada proses operasi pintu dock, pekerja harus dapat berjalan dan bekerja dengan leluasa di atas pintu. Pada saat pintu beroperasi, di atas pintu akan ada beberapa orang yang bertugas untuk membuka valve air balas maupun beraktivitas yang lain. Pada Gambar 6 terlihat simulasi pekerja yang beraktivitas di atas pintu dock.

Perhitungan konstruksi pada penelitian ini menggunakan rules Biro Klasifikasi Indonesia, Volume II Rules for Hull tahun 2009 [11]. Terdapat beberapa variasi jarak antar pembujur dilakukan yaitu jarak pembujur $0.55 \mathrm{~m}, 0.60 \mathrm{~m}$, $0.65 \mathrm{~m}$ dan $0.70 \mathrm{~m}$.

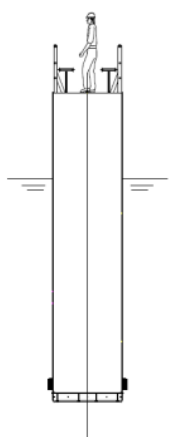

Gambar 6. Pekerja beraktivitas di pintu dock

Tabel 1. Ukuran Tebal Pelat

\begin{tabular}{|c|c|c|c|c|}
\hline \multirow{2}{*}{$\begin{array}{l}\text { Variasi Jarak } \\
\text { Pembujur (m) }\end{array}$} & \multicolumn{4}{|c|}{ Tebal Pelat (mm) } \\
\hline & Alas & Sisi & Geladak & Sekat \\
\hline 0.55 & 14 & 9 & 7 & 6 \\
\hline 0.60 & 14 & 10 & 7 & 6 \\
\hline 0.65 & 14 & 10 & 7 & 6 \\
\hline 0.70 & 14 & 11 & 7 & 6 \\
\hline
\end{tabular}

Tabel 2. Ukuran Profil Konstruksi Variasi $0.55 \mathrm{~m}$

\begin{tabular}{|c|c|c|}
\hline No & Konstruksi & Profil \\
\hline 1 & \multicolumn{2}{|c|}{ Konstruksi Alas } \\
\hline \multirow{4}{*}{2} & Wrang/Girder & $\mathrm{h}=0.6 \mathrm{~m}, \mathrm{t}=9 \mathrm{~mm}$ \\
\hline & \multicolumn{2}{|c|}{ Konstruksi Lambung/Sisi } \\
\hline & Senta/Web Frame & $\mathrm{T} 400 \times 300 \times 12$ \\
\hline & Pembujur Sisi & I $130 \times 10$ \\
\hline \multirow[t]{4}{*}{3} & \multicolumn{2}{|c|}{ Konstruksi Geladak } \\
\hline & Balok & I $75 \times 8$ \\
\hline & Balok Besar & I $120 \times 12$ \\
\hline & Penumpu Tengah & I $75 \times 10$ \\
\hline \multirow[t]{3}{*}{4} & \multicolumn{2}{|c|}{ Konstruksi Sekat } \\
\hline & Penegar & I 130x10 \\
\hline & Penumpu & T 400x300x12 \\
\hline
\end{tabular}

Tabel 3. Ukuran Profil Konstruksi Variasi $0.60 \mathrm{~m}$

\begin{tabular}{|c|c|c|}
\hline No & Konstruksi & Profil \\
\hline 1 & \multicolumn{2}{|c|}{ Konstruksi Alas } \\
\hline \multirow{4}{*}{2} & Wrang/Girder & $\mathrm{h}=0.6 \mathrm{~m}, \mathrm{t}=9 \mathrm{~mm}$ \\
\hline & \multicolumn{2}{|c|}{ Konstruksi Lambung/Sisi } \\
\hline & Senta/Web Frame & $\mathrm{T} 400 \times 300 \times 12$ \\
\hline & Pembujur Sisi & I $120 \times 10$ \\
\hline \multirow[t]{4}{*}{3} & \multicolumn{2}{|c|}{ Konstruksi Geladak } \\
\hline & Balok & I $75 \times 8$ \\
\hline & Balok Besar & I $120 \times 12$ \\
\hline & Penumpu Tengah & I $75 \times 10$ \\
\hline \multirow[t]{3}{*}{4} & \multicolumn{2}{|c|}{ Konstruksi Sekat } \\
\hline & Penegar & I $120 \times 12$ \\
\hline & Penumpu & $\mathrm{T} 400 \times 300 \times 12$ \\
\hline
\end{tabular}

Tabel 4. Ukuran Profil Konstruksi Variasi $0.65 \mathrm{~m}$

\begin{tabular}{ccc}
\hline No & Konstruksi & Profil \\
\hline 1 & \multicolumn{2}{c}{ Konstruksi Alas } \\
& Wrang/Girder & $\mathrm{h}=0.6 \mathrm{~m}, \mathrm{t}=9 \mathrm{~mm}$ \\
2 & \multicolumn{2}{c}{ Konstruksi Lambung/Sisi } \\
& Senta/Web Frame & T 400x300x12 \\
& Pembujur Sisi & I 140x10 \\
3 & & Konstruksi Geladak \\
\hline
\end{tabular}




\begin{tabular}{|c|c|c|}
\hline & Balok & I $75 \times 8$ \\
\hline \multirow{5}{*}{4} & Balok Besar & I $120 \times 12$ \\
\hline & Penumpu Tengah & I $75 \times 10$ \\
\hline & \multicolumn{2}{|c|}{ Konstruksi Sekat } \\
\hline & Penegar & I $140 \times 12$ \\
\hline & Penumpu & $\mathrm{T} 400 \times 300 \times 12$ \\
\hline
\end{tabular}

Tabel 5. Ukuran Profil Konstruksi Variasi $0.70 \mathrm{~m}$

\begin{tabular}{|c|c|c|}
\hline No & Konstruksi & Profil \\
\hline 1 & \multicolumn{2}{|c|}{ Konstruksi Alas } \\
\hline \multirow{4}{*}{2} & Wrang/Girder & $\mathrm{h}=0.6 \mathrm{~m}, \mathrm{t}=9 \mathrm{~mm}$ \\
\hline & \multicolumn{2}{|c|}{ Konstruksi Lambung/Sisi } \\
\hline & Senta/Web Frame & $\mathrm{T} 400 \times 300 \times 12$ \\
\hline & Pembujur Sisi & I $120 \times 13$ \\
\hline \multirow[t]{4}{*}{3} & \multicolumn{2}{|c|}{ Konstruksi Geladak } \\
\hline & Balok & I $75 \times 8$ \\
\hline & Balok Besar & I $120 \times 12$ \\
\hline & Penumpu Tengah & I $75 \times 10$ \\
\hline \multirow[t]{3}{*}{4} & \multicolumn{2}{|c|}{ Konstruksi Sekat } \\
\hline & Penegar & I $120 \times 13$ \\
\hline & Penumpu & T $400 \times 300 \times 12$ \\
\hline
\end{tabular}

Pada Tabel 1 hingga Tabel 5, dapat dilihat detail ukuran profil serta pelat pada masingmasing pintu dock. Ukuran profil dan pelat yang ada merupakan hasil perhitungan dengan menggunakan Rules Biro Klasifikasi Indonesia, Volume II Rules for Hull tahun 2009, hasil ukuran profil dan pelat menjadi acuan untuk proses perhitungan dengan metode elemen hingga yang dibantu dengan software dan untuk perhitungan berat konstruksi yang akan digunakan untuk menghitung building cost. Pada Gambar 8 dapat dilihat desain construction profile pintu dock dengan jarak pembujur $0.6 \mathrm{~m}$. Pintu dock pada penelitian ini memiliki dua buah sekat, seperti terlihat pada Gambar 9.

\subsection{Beban dan Kondisi Batas}

Pada penelitian ini, beban yang diaplikasikan pada pintu dock adalah beban hidrostatis air laut serta air balas. Dengan sarat ketinggian pada saat beroperasi adalah $6,5 \mathrm{~m}$.

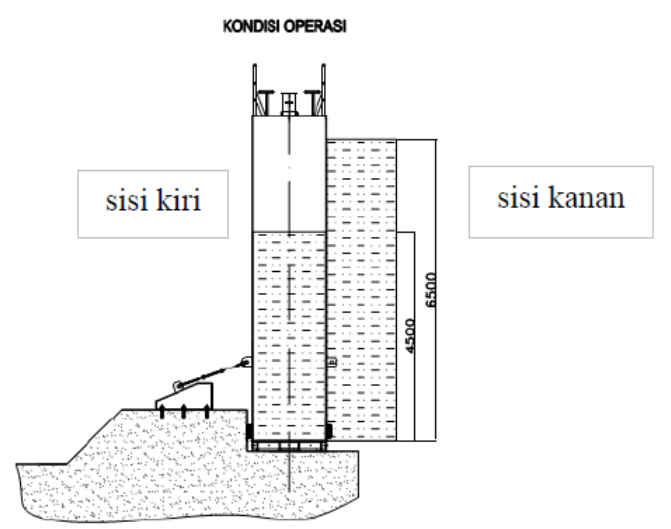

Gambar 7. Kondisi pada saat beroperasi

$$
P_{h}=\rho \cdot g \cdot h
$$

Dimana :

$\mathrm{Ph}=$ Tekanan hirostatik $\left(\mathrm{N} / \mathrm{m}^{2}\right)$

$\mathrm{h}=$ Jarak ke permukaan zat cair $(\mathrm{m})$

$\rho=$ Massa jenis zat cair $\left(\mathrm{kg} / \mathrm{m}^{3}\right)$

$\mathrm{g}=\operatorname{Gravitasi}\left(\mathrm{m} / \mathrm{s}^{2}\right)$

Pada saat sarat penuh maka, beban tekanan hidrostatik yang dialami oleh pintu dock :

Tekanan Air Laut (Psw)

$$
P_{S W}=\rho \cdot g \cdot h
$$

$\mathrm{h}=6.5 \mathrm{~m}$

$\rho=1025 \mathrm{Kg} / \mathrm{m}^{3}$

$\mathrm{g}=9.81 \mathrm{~m} / \mathrm{s}^{2}$

$\mathrm{Psw}=65359.125 \mathrm{~N} / \mathrm{m}^{2}$

Tekanan Air Balas $\left(\mathrm{P}_{\mathrm{WB}}\right)$

$$
P_{W B}=\rho \cdot g \cdot h
$$

$\mathrm{h}=4.5 \mathrm{~m}$

$\rho=1025 \mathrm{Kg} / \mathrm{m}^{3}$

$\mathrm{g}=9.81 \mathrm{~m} / \mathrm{s}^{2}$

$$
\mathrm{P}_{\mathrm{WB}}=45248.625 \mathrm{~N} / \mathrm{m}^{2}
$$

Kondisi batas pada penelitian ini dapat dilihat pada Gambar 10, terlihat kondisi batas diaplikasikan pada sisi depan pintu dock. Kondisi batas ini diasumsikan pada fender pintu dock yang menempel pada dock pada saat beroperasi. Pada Gambar 10 terlihat rotasi (ROT) dan translasi (U) yang dapat terjadi pada pintu dock, rotasi bernilai nol menandakan pada arah tersebut pintu tidak dapat berotasi, sedangkan translasi bernilai nol menandakan pintu tidak dapat bertranlasi.

Pada penelitian ini, material baja yang digunakan adalah A36 dengan material properties massa jenis $7.800 \mathrm{~kg} / \mathrm{m}^{3}(0,28 \mathrm{lb} / \mathrm{cu}$ in), Modulus Young $200 \mathrm{GPa}(29.000 .000$ psi), baja A36 memiliki rasio Poisson sebesar 0.26, dan modulus geser $75 \mathrm{GPa}$ (10.900.000 psi).

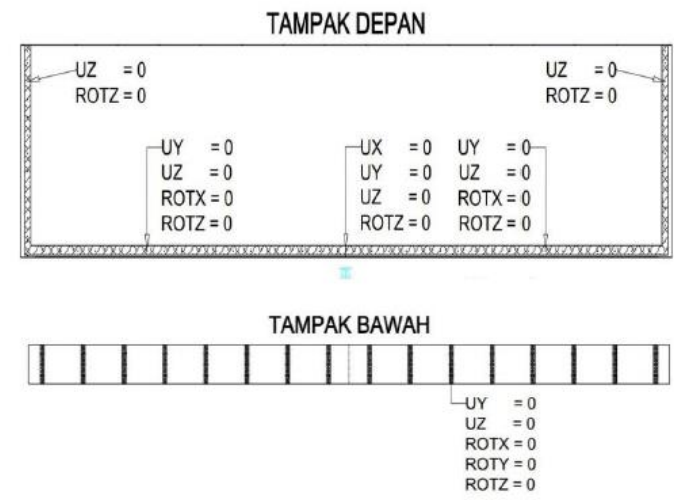

Gambar 8. Kondisi batas pintu dock 


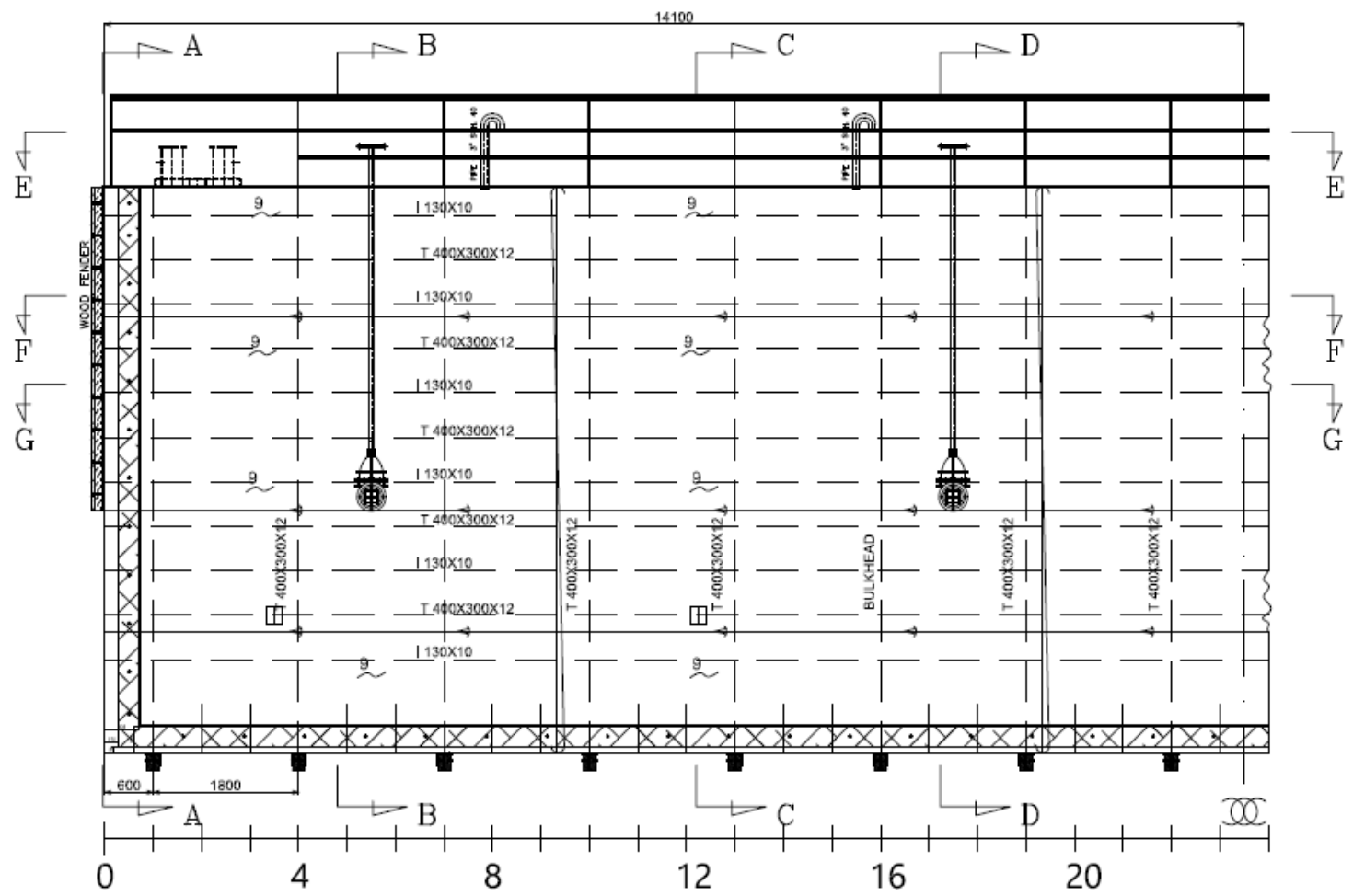

Gambar 9. Construction profile pintu dock dengan jarak pembujur $0.6 \mathrm{~m}$
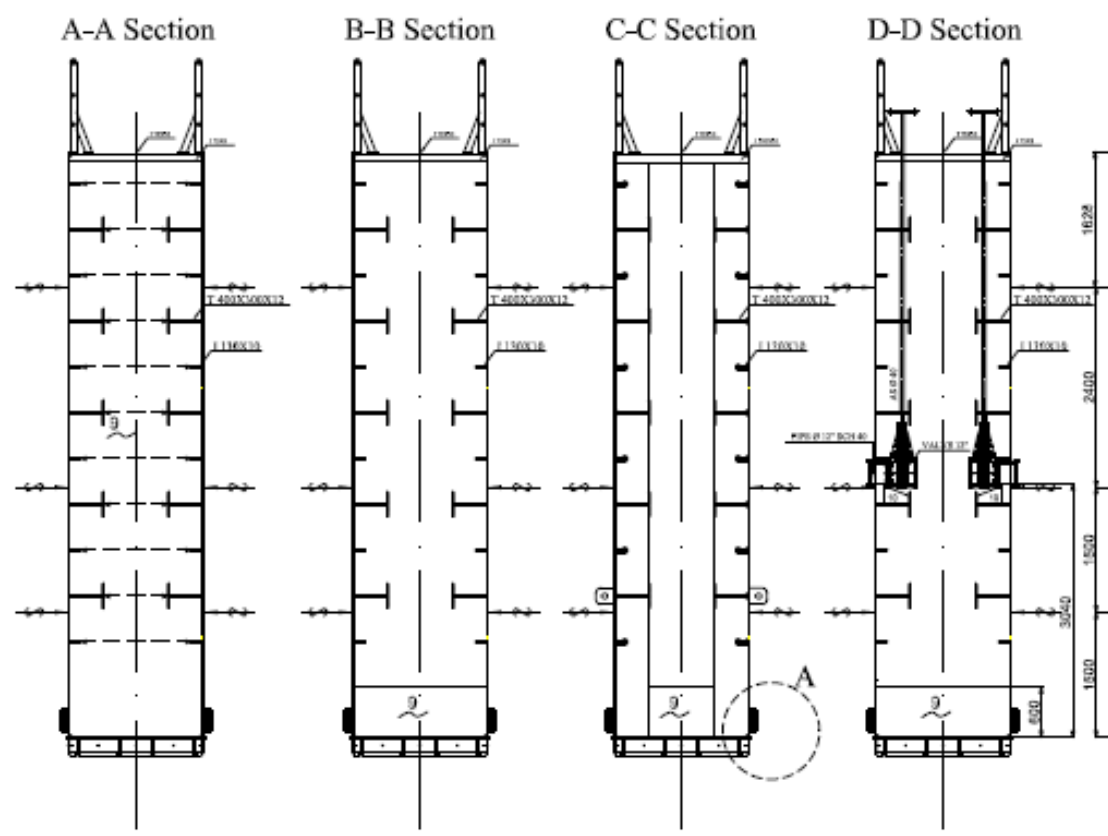

Bulkhead

Gambar 10. Tampak potongan melintang

\section{HASIL DAN PEMBAHASAN}

Pada penelitian ini, perhitungan kekuatan pintu dock menggunakan metode elemen hingga dibantu software dilakukan dengan pemodelan terlebih dahulu seperti pada Gambar 11, dengan pemodelan yang baik maka didapatkan hasil yang akurat. Terlihat pada Gambar 11 potongan pemodelan struktur, terlihat pembujur dan sekat yang telah dimodelkan.

Pada Gambar 12 dapat dilihat tampak model pintu dari arah depan yang telah di-meshing. Pemodelan struktur untuk pembujur dan penegar lainnya menggunakan Element Beam 189 sedangkan untuk pelat menggunkan Elemen SHELL 181. Elemen BEAM 189 cocok untuk menganalisis struktur balok tipis hingga cukup 
tebal. Elemen ini didasarkan pada teori balok Timoshenko yang meliputi efek geser-deformasi. Elemen SHELL 181 cocok untuk menganalisis struktur plat tipis hingga cukup tebal. Elemen ini adalah elemen empat simpul dengan enam derajat kebebasan pada setiap node [10].

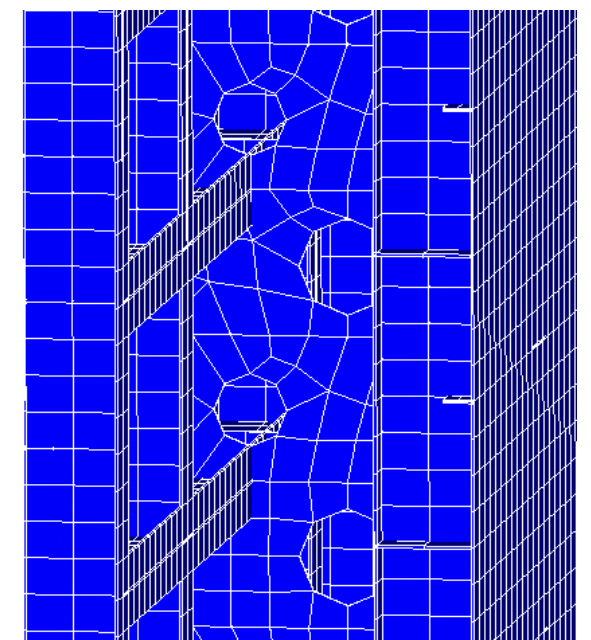

Gambar 11. Potongan pemodelan struktur pada software

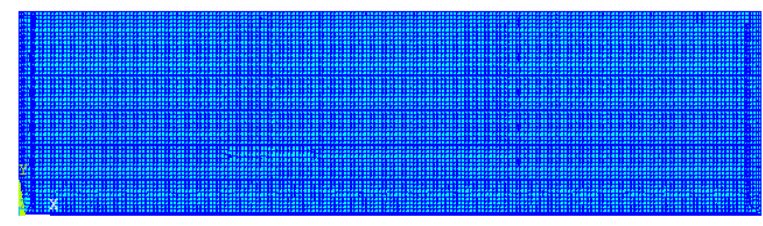

Gambar 12. Tampak depan struktur yang telah dimeshing

Konvergensi merupakan salah satu tahap penting dalam pemodelan menggunakan software elemen hingga, akurasi hasil pemodelan elemen hingga semakin meningkat mendekati hasil exact solution dengan semakin banyaknya elemen yang digunakan. [8].

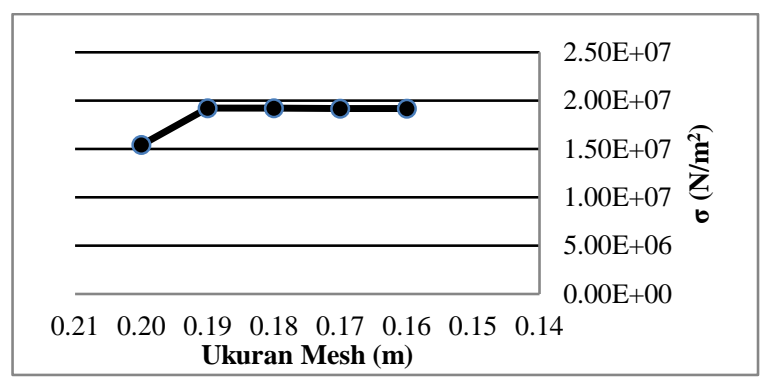

Gambar 13. Konvergensi mesh

Dengan mereduksi ukuran mesh maka jumlah elemen akan semakin meningkat. Dengan jumlah elemen yang semakin banyak, maka dibutuhkan waktu yang besar pula untuk proses komputasi. Ukuran mesh yang tepat perlu dicari agar nilai dari hasil perhitungan mendekati kondisi nyata dan kapasitas komputer yang digunakan tetap memadai. Di dalam penelitian ini, sebelum melakukan running, maka dilakukan terlebih dahulu konvergensi pada konstruksi gate dock. Dengan menggunakan beberapa ukuran mesh yaitu $0.20 \mathrm{~m}$ sampai $0.16 \mathrm{~m}$, didapatkan hasil yaitu pada ukuran mesh $0.19 \mathrm{~m}$ hingga $0.16 \mathrm{~m}$, hasil pada pemodelan sudah tidak berubah dan konstan terlihat dari Gambar 12, sehingga dapat diambil kesimpulan bahwa mesh ukuran 0.16 sudah konvergensi, maka untuk selanjutnya pemodelan menggunakan mesh ukuran $0.16 \mathrm{~m}$.

Deformasi daripada gate dock seperti terlihat pada Gambar 14, dengan model gambar deformasi auto calculate untuk memudahkan visualisasi, dengan bentuk deformasi melengkung yang menandakan bahwa bekerja pada satu sisi. Pada Gambar 14 terlihat deformasi terendah ditandai dengan warna biru, dan deformasi terbesar ditandai dengan warna merah, pada penelitian ini deformasi terbesar terjadi pada sisi bawah pintu dock.

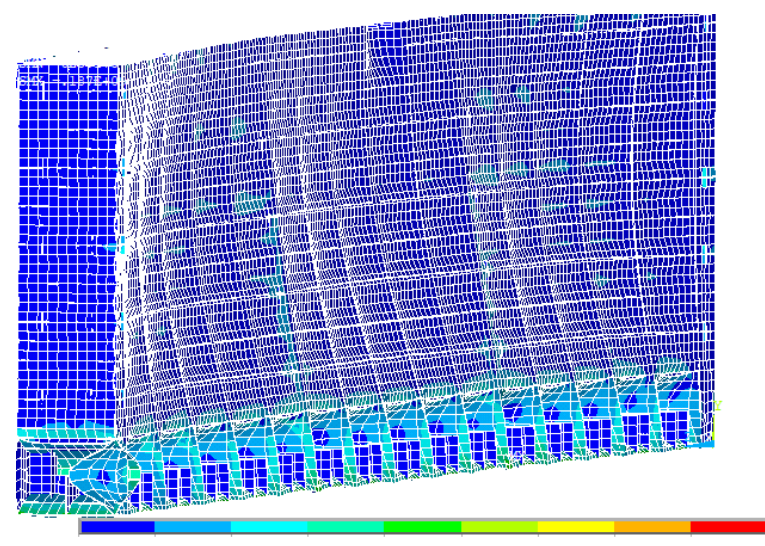

Gambar 14. Deformasi yang terjadi

Besarnya maksimum stress von Mises yang terjadi pada gate dock ini yaitu konstruksi dengan jarak pembujur $0.55 \mathrm{~m}$ memiliki tegangan maksimum von Mises $155.84 \mathrm{~N} / \mathrm{mm}^{2}$, dan jarak pembujur $0.70 \mathrm{~m}$ memiliki tegangan maksimum von Mises terendah yaitu $108.58 \mathrm{~N} / \mathrm{mm}^{2}$.

Pada Tabel 6 terlihat, tegangan von Mises pada setiap variasi pembujur semakin menurun besarnya, ini dikarenakan pada setiap jarak pembujur memiliki ukuran profile yang berbeda. Dapat dilihat pada Tabel 2 hingga Tabel 5, ukuran profile pembujur pada setiap variasi berbeda, semakin besar jarak pembujur maka semakin besar pula ukuran profile yang dihasilkan, ini yang menyebabkan nilai hasil tegangan von Mises yang terjadi semakin kecil. Karena dengan beban yang sama dan ukuran profile yang semakin besar menyebabkan nilai tegangan von Mises yang dihasilkan semakin kecil hal ini menandakan semakin kuat konstruksi yang didesain. 
Tabel 6. Tegangan maksimum von Mises

\begin{tabular}{clc}
\hline No & Jarak Pembujur (m) & $\begin{array}{c}\text { Tegangan von } \\
\text { Mises (N/mm }\end{array}$ \\
\hline 1 & Pembujur $0.55 \mathrm{~m}$ & 155.84 \\
2 & Pembujur $0.60 \mathrm{~m}$ & 142.99 \\
3 & Pembujur $0.65 \mathrm{~m}$ & 132.19 \\
4 & Pembujur $0.70 \mathrm{~m}$ & 108.58 \\
\hline
\end{tabular}

Pada rules Biro Klasifikasi Indonesia Volume II Rules for Hull (2009), menyebutkan bahwa "kekuatan normal baja konstruksi lambung adalah suatu baja konstruksi lambung dengan nilai luluh atas minimum $\mathrm{ReH} 235 \mathrm{~N} / \mathrm{mm}^{2}$ dan kuat tarik Rm $400-520 \mathrm{~N} / \mathrm{mm}^{20}$. Dan dapat dilihat bahwa hasil pemodelan serta perhitungan gate dock menunjukkan masing-masing konstruksi memiliki tegangan di bawah $\mathrm{ReH}$, sehingga konstruksi gate dock yang didesain memenuhi standar yang ada.

Tabel 7. Deformasi Tiap Desain Pintu

\begin{tabular}{clc}
\hline No & Jarak Pembujur (m) & $\begin{array}{c}\text { Deformasi von } \\
\text { Mises }(\mathbf{m m})\end{array}$ \\
\hline 1 & Pembujur $0.55 \mathrm{~m}$ & 0.211 \\
2 & Pembujur $0.60 \mathrm{~m}$ & 0.190 \\
3 & Pembujur $0.65 \mathrm{~m}$ & 0.174 \\
4 & Pembujur $0.70 \mathrm{~m}$ & 0.149 \\
\hline
\end{tabular}

Pada Tabel 7 dapat dilihat deformasi von Mises yang terjadi, pada variasi pembujur $0.55 \mathrm{~m}$ terjadi deformasi sebesar $0.211 \mathrm{~mm}$, dan variasi pembujur $0.70 \mathrm{~m}$ terjadi deformasi sebesar 0.149 $\mathrm{mm}$. Penurunan nilai deformasi terjadi seiring dengan penambahan jarak pembujur, hasil ini terjadi karena adanya efek penambahan ketebalan pelat dan semakin besarnya ukuran profile sehingga dengan kondisi beban yang sama, menghasilkan nilai deformasi von Mises yang semakin kecil.

Tabel 8 Berat Konstruksi Pintu

\begin{tabular}{clc}
\hline No & Jarak Pembujur (m) & $\begin{array}{c}\text { Berat Konstruksi } \\
\text { (Kg) }\end{array}$ \\
\hline 1 & Pembujur $0.55 \mathrm{~m}$ & 79671.37 \\
2 & Pembujur $0.60 \mathrm{~m}$ & 82793.16 \\
3 & Pembujur $0.65 \mathrm{~m}$ & 78784.66 \\
4 & Pembujur $0.70 \mathrm{~m}$ & 81716.00 \\
\hline
\end{tabular}

Pada Tabel 8 dapat dilihat berat konstruksi tiap desain pintu dock, hasil perhitungan menunjukkan pintu dock dengan jarak pembujur $0.65 \mathrm{~m}$ memiliki berat konstruksi terkecil dan pada pembujur $0.60 \mathrm{~m}$ memiliki berat konstruksi terbesar. Hal ini disebabkan karena ukuran pelat dan profile yang berbeda pada setiap variasi pembujur. Lihat pada Tabel 1 hingga 5, pada variasi pembujur $0.65 \mathrm{~m}$ memiliki ketebalan profile $10 \mathrm{~mm}$ sedangkan pada pembujur $0.6 \mathrm{~m}$ memiliki ketebalan profile sebesar $12 \mathrm{~mm}$.

Biaya pembangunan atau building cost menggunakan perhitungan pendekatan berat konstruksi, dengan rumus pendekatan :

\section{Building Cost = biaya baja+biaya consumable+biaya jasa pekerja}

Dimana consumable adalah 5\% dari berat konstruksi. Dengan biaya baja per kilogramnya adalah sebesar Rp 9.000,00, consumbale sebesar Rp 26.000,00 dan jasa pekerja untuk pembangunan adalah sebesar Rp. 4000 perkilogramnya. Hasil perhitungan building cost dapat dilihat pada Tabel 9, dimana pintu dock dengan variasi jarak pembujur $0.65 \mathrm{~m}$ memiliki building cost terendah yaitu Rp1,126,620,674 sedangkan pintu dengan variasi pembujur $0.60 \mathrm{~m}$ memiliki building cost terbesar yaitu Rp1,183,942,203.

Tabel 9 Building Cost

\begin{tabular}{|c|c|c|}
\hline \\
\hline No & Jarak Pembujur (m) & Building Cost (Rp) \\
\hline 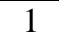 & Pembujur $0.55 \mathrm{~m}$ & Rp1,139,300,545 \\
\hline 2 & Pembujur $0.60 \mathrm{~m}$ & Rp1,183,942,203 \\
\hline 3 & Pembujur $0.65 \mathrm{~m}$ & Rp1,126,620,674 \\
\hline 4 & Pembujur $0.70 \mathrm{~m}$ & Rp1,168,538,826 \\
\hline
\end{tabular}

\section{KESIMPULAN}

Setelah dilakukan proses perhitungan kekuatan dengan metode elemen hingga, dapat. disimpulkan bahwa dengan adanya variasi jarak pembujur, tegangan maksimum von Mises masih dibawah nilai ReH dari Rules BKI volume 2 tahun 2009 dan pintu dock dengan jarak jarak pembujur $0.7 \mathrm{~m}$ memiliki tegangan maksimum von Mises yang terendah yaitu $108.58\left(\mathrm{~N} / \mathrm{mm}^{2}\right)$ serta pintu dock dengan jarak pembujur $0.55 \mathrm{~m}$ memiliki tegangan maksimum von Mises terbesar yaitu $155.84 \mathrm{~N} / \mathrm{mm}^{2}$. Perhitungan building cost menghasilkan dimana pintu dock dengan variasi jarak pembujur $0.65 \mathrm{~m}$ memiliki building cost terendah yaitu Rp1,126,620,674 sedangkan pintu dengan variasi pembujur $0.60 \mathrm{~m}$ memiliki building cost terbesar yaitu Rp1,183,942,203.

\section{DAFTAR PUSTAKA}

[1] Heger, Robert. Dockmaster's Training Manual. Holliston : Heger Dry Dock Inc, 2005.

[2] Royalhaskoningdhv. Dock \& Lock Gates. Netherlands, 2018.

[3] Oktoberty, Widiyanto, E, J, Sasono, S, Pramono and A,T, Wandono. "Dry Dock 
Gate Stability Modelling”. IOP Conf. Series: Journal of Physics: Conf. Series 983, 2018.

[4] Bogdaniuk, Marian and Gerocki, Zenon. "Design of Inner Gate for CRIST Shipyard Dry Dock". Polish Maritime Research 1(72) 2012 Vol 19; pp. 52-56

[5] Budianto. "Strength Structure Analysis of Main Gate Graving Dock Using Pontoons for Condition Repairs". Makara J. Technol. 22/2, 109-114, 2018.

[6] Liu, Bin and Soares, C. Guedes, "Assessment of the strength of double-hull tanker side structures in minor ship collisions". Engineering Structures, vol. 120, pp. 1-12, 2016.

[7] Ertas, Ahmet H. Alkan, Veysel and Fatih, Ahmet. "Finite Element Simulation of a Mercantile Vessel Shipboard Under Working Conditions". Procedia Engineering, vol. 69 pp. 1001 - 1007. 2014

[8] Logan, Daryl L. A First Course in the Finite Element Method, Fourth Edition. Kanada: Thomson, 2007.

[9] Stolarski, T.A, Nakasone. Y and Yoshimoto. S, Engineering Analysis With ANSYS Software. Elsevier Butterworth-Heinemann, 2006.

[10] ANSYS, ANSYS Mechanical APDL Structural Analysis Guide, ANSYS Inc, Pennsylvania, 2013.

[11] Biro Klasifikasi Indonesia Volume II. Rules for Hull. 2009. 